\author{
ИЗВЕСТИЯ АКАДЕМИИ НАУК ЭСТОНСКОЙ ССР. ТОМ VII \\ СЕРИЯ БИОЛОГИЧЕСКАЯ. 1958, 스 3
}

\title{
ИЗУЧЕНИЕ РЕФЛЕКСА МОЛОКООТДАЧИ ПРИ МАШИННОЙ ДОЙКЕ
}

\section{Э. К. ВАЛЬДМАН}

Целью настоящей работы являлось изучение влияния различных внешних факторов, - в том числе массажа и температурной обработки вымени, изменения режима доения и числа пульсации доильного аппарата, - на процесс молокоотдачи при машинном доении коров.

Изучалась также возможность характеристики индивидуальных особенностей коров на основании рефлекса молокоотдачи в условиях машинного доения.

\section{Методика работы}

Графическая регистрация динамики молокоотдачи при машинной дойке проводилась автоматическими весами типа «Беркель» и кимографом.

Показателями для характеристики полученных кривых динамики молокоотдачи служили количество надоенного молока в килограммах, продолжительность дойки доильной машиной в минутах и среднее количество молока, надоенного в течение каждой минуты дойки

$$
\left(\frac{\text { количество надоенного молока в кг }}{\text { продолжительность дойки доильной машиной в мин. }}\right) \text {. }
$$

Ежедневно учитывалось количество молока, надоенного за сутки, и определялся процент жира в нем.

Дойка производилась советской трехтактной доильной машиной при вакууме $38 \mathrm{~cm}$ ртутного столба. Число пульсаций обычно (кроме специальных опытов с изучением эффекта пульсации различной частоты) равнялось 48 в минуту.

Опыты были проведены в 1954-1955 гг. во время стойлового периода в условиях двухпромежуточного распорядка дня по Жолниренко (1954). При указанном распорядке дня, состоящем из двух законченных циклов работ - утреннего и вечернего, сближены первая и вторая, третья и четвертая дойки. Если при равномерном распорядке дня промежуток между началом первой и второй дойками равен 5 часам 30 минутам, то при двухпромежуточном распорядке дня он равен лишь 3 часам. Такой же трехчасовой промежуток установлен между третьей и четвертой дойками; промежуток между второй и третьей, четвертой и первой дойками равен при этом 9 часам.

Подопытными животными служили 14 коров голландской и латвийской бурой пород стада научно-опытной станции Института физиологии им. И. П. Павлова АН СССР с годовой продуктивностью 2700-6000 кг молока,

Всего зарегистрировано графически 1652 дойки.

\section{Результаты опытов}

Наблюдения показали, что суточный удой по группе подопытных коров распределяется по дойкам в среднем следующим образом: первая дойка давала $34,6 \%$ суточного удоя, вторая - 17,7 , третья - 33,8 и четвертая $13,9 \%$. Однако это не является абсолютной закономерностью, так как трое животных регулярно давали наибольшее количество молока не в 
первую, а в' третью дойку (например корова Вира давала в первую дойку 29,6 , во вторую - 20,0 , в третью - 34,7 и в четвертую $-15,7 \%$ суточного надоя). Наибольшая скорость молокоотдачи отмечалась при основных дойках, где среднее количество молока, надоенного в минуту, у отдельных коров доходило до трех килограммов.

При дополнительных дойках (через 3-часовой интервал) продолжительность дойки увеличивалась в $1,05-1,75$ раза, а среднее количество молока, надоенного в минуту, уменьшалось по сравнению с основными дойками в $2-8$ раз.

Значительно возрастал в дополнительные дойки латентный период рефлекса молокоотдачи. Если в основные дойки длительность латентного периода колебалась у различных животных в пределах 20-95 секунд, то при дополнительной дойке (поддое) она доходила до $72-238$ секунд.

Изучение влияния подготовительного массажа вымени и сосков на скорость молокоотдачи показало, что наиболее эффективным оказался массаж, который по своей продолжительности равнялся латентным периодам рефлекса молокоотдачи. В результате предварительного массажа вымени указанной длительности время доения. сокращалось у различных коров при основных дойках на 17,8-29,3\%. Количество молока, выдаиваемого в этих случаях в минуту, увеличивается соответственно на $23,1-48,7 \%$ по сравнению с величиной удоя при доении без предварительного массажа вымени.

При дополнительных дойках эффект предварительного массажа вымени выражался еще рельефнее. Так, у некоторых животных, обладающих значительным латентным периодом рефлекса молокоотдачи, время доения сокращалось после массажа до $50 \%$, а среднее количество молока, выдаиваемого в' минуту, увеличивалось до $60,8 \%$. При этом следует, правда, отметить, что хотя предварительным массажем вымени перед второй и четвертой дойками можно значительно сократить время работы доильной машины, эти дойки у большинства животных по сравнению с основными малоэффективны, так как на выдаивание одного литра молока при дополнительных дойках требуется в целом значительно больше времени. Так, вследствие удлинения латентного периода рефлекса молокоотдачи, доярке приходится предв'арительно массажировать вымя иногда до 4 минут, пока вступает в действие рефлекс молокоотдачи.

Сравнительное изучение влияния термических раздражений вымени в виде обтирания полотенцем, смоченным водой температурой +10 , $+32-36$ и $+52-56^{\circ} \mathrm{C}$, и массажа сухим полотенцем на скорость молокоотдачи показало отсутствие преимущества «горячего» обмывания перед другими приемами подготовки вымени. Характер молокоотдачи оставался при всех этих манипуляциях практически одинаковым. Не изменялись также колебания суточной продукции молока и содержание жира в нем.

Нарушение привычного режима дойки путем нерегулярного чередования машинного доения с ручным вызывало у всех коров' изменения в характере молокоотдачи. Так, время доения увеличивалось на $11,3-260,0 \%$, а среднее количество молока, выдаиваемого в минуту, уменьшалось на $24,3-34,6 \%$ по сравнению с исходным.

Опыты с изучением влияния числа пульсаций доильного аппарата на молоковыделительный рефлекс дали следующие результаты: если исходные показатели скорости выдаивания, полученные в условиях доения коров при рекомендуемой конструктором (Королев, 1953) частоте работы аппарата (48 пульсаций в минуту), принять за $100 \%$, то выясняется, что перевод ритма пульсатора на 24 пульсации в минуту вызывал увеличение времени доения на $26,3-50 \%$, а среднее количество молока, выдаивае- 
мого в минуту, уменьшалось на 26,9-33,6\%: Работа аппарата при ритме 96 пульсаций в минуту позволила уменьшить время доения на $2,2-6,4 \%$ и увеличить среднее количеств' молока, выдаиваемого в минуту, на $2,2-9,8 \%$ : Работа аппарата со скоростью 150 пульсаций в минуту приводила к уменьшению времени доения на $5,3-8,7 \%$, а среднее количество молока, выдаиваемого в минуту, увеличивалось на $6,5-14 \%$.

В связи с тем, что ряд подопытных животных отличался медленной отдачей молока (тугодойкостью), на них были проведены опыты по изучению скорости выдаивания после выключения сопротивления соскового сфинктера с помощью катетера.
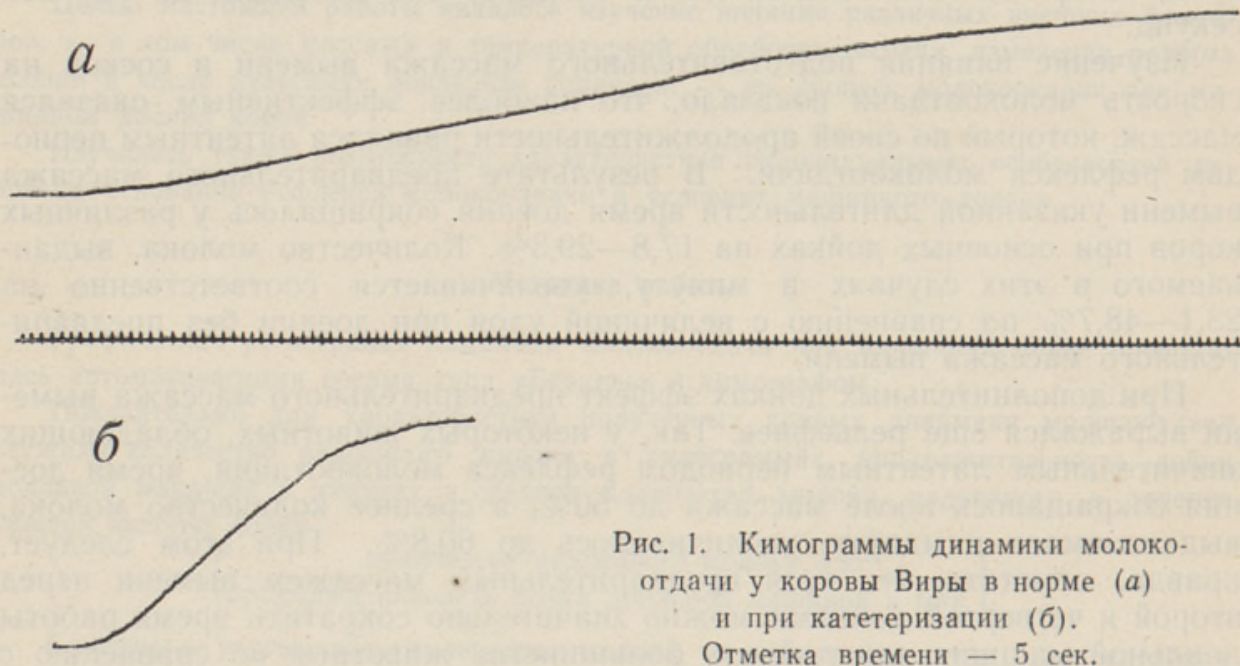

Рис. 1. Кимограммы динамики молокоотдачи у коровы Виры в норме (a)

и при катетеризации (б).

Отметка времени - 5 сек.

О существенном значении тонуса соскового сфинктера на скорость молокоотдачи при машинном доении свидетельствует графическая запись молокоотдачи у коровы Виры (рис. $1 a, \sigma)$. Первая (рис. 1a) представляет кривую молокоотдачи в норме; вторая (рис. 1б) получена при одновременном выключении катетерами сопротивления сфинктеров в'ех четыpeх сосков. Следует, однако, отметить, что при повторных доениях в аналогичных условиях и в дальнейшем наблюдались колебания в скорости молокоотдачи, св'ойственные этой корове и в норме, однако они были выражены гораздо слабее.

При машинном доении наблюдаются существенные индивидуальные различия в динамике молокоотдачи у отдельных коров.

Так, наблюдая за динамикой молокоотдачи, видно, что животные как одинаковой, так и различной молочной продуктивности не доятся с одинаковой скоростью. Например, если у коровы Ласточки для выдаивания 8 кг молока во время основных доек требуется 5 минут, то Ветка отдает такое же количество молока в течение 11 минут. У коровы Музы 5,5 кг молока выдаивается в течение 3,5 минут, у Шпинатки для этого требуется более 6 минут. В то же время корова Березка отдает около $11 \mathrm{kг}$ молока в течение 4 минут. 
Следовательно, прямой корреляции между величиной разового удоя коровы и скоростью выдаивания не наблюдается.

Динамика молокоотдачи у коров при машинном доении подвергается колебаниям как из дойки в дойку, так и гзо дня в' день, причем у отдельных коров наблюдается различный диапазон колебаний рефлекса молоко. отдачи.

Если, например, у коровы Музы колебания продолжительности дойки доильной машиной в течение 4-месячного периода наблюдения доходили лишь до одной минуты, то у ее сверєтницы Незабудки, находившейся в той же стадии лактации, разница в скорости выдаивания одного и того же количества молока колебалась в пределах 9 минут.

\section{HE3AБYAKA}

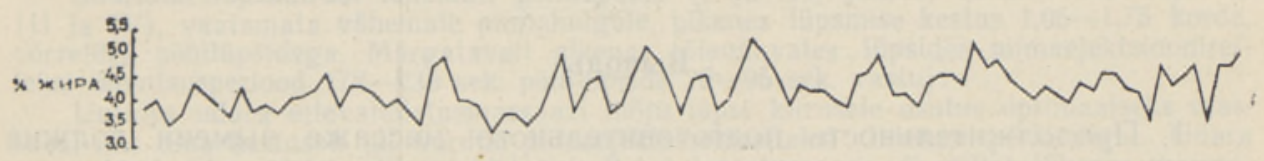

Рис. 2. Ежедневные колебания содержания молочного жира в суточном удое молока у коровы Незабудки.

Сопоставляя кривые молокоотдачи с колебаниями содержания жира в суточном удое молока, бросается в глаза, что наибольшие колебания содержания молочного жира наблюдаются у животных с более лабильными кривыми динамики молокоотдачи. И в данном случае это явление обнаруживается более отчетливо у коровы Незабудки (рис. 2), чем у Музы (рис. 3).

\section{MY3A}

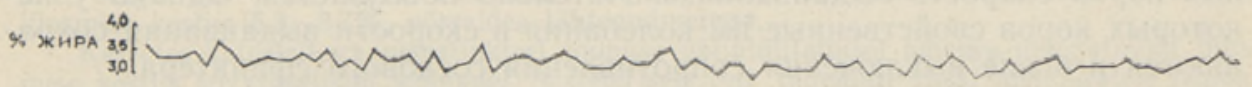

Рис. 3. Ежедневные колебания содержания молочного жира в суточном удое молока у коровы Музы.

Анализ кривых рефлекса молокоотдачи, полученных у подопытных животных при ранее описанных опытных условиях, показали, что коровы с наибольшим размахом колебаний как в динамике молокоотдачи, так и по колебаниям содержания молочного жира имеют относительно непостоянную величину латентного периода рефлекса молокоотдачи. Влияние подготовительного массажа на рефлекс молокоотдачи у этих коров выражено слабее, чем у коров, отличающихся более стабильными кривыми молокоотдачи.

При переводе пульсатора с одного ритма работы на другой (в частности, при переводе с 48 пульсаций в минуту на 24 и обратно) коровы со стабильной молокоотдачей сразу отчетливо реагировали на перемену ритма. В то же время коровы с нестабильным рефлексом молокоотдачи совсем не реагировали на эту перемену или же реагировали через несколько доек.

У шести подопытных животных методом пищевых условных рефлексов Э. П. Кокориной были определены типы высшей нервной деятельности. 
При сопоставлении этих данных с нашими оказалось, что у коров, сбладающих хорошей подвижностью корковых нервных процессов, малоколеблющийся стойкий рефлекс молокоотдачи. Қоровы с плохой подвижностью нервных процессов характеризуются лабильной молокоотдачей.

Таким образом, наряду с анатомическими факторами (сильный сосковый сфинктер), скорость выдаивания при дойке машиной в значительной мере определяется индивидуальными особенностями нервной системы коровы. Наиболее подходящими для машинного доения являются животные, характеризующиеся стойким рефлексом молокоотдачи. Наличие в стаде коров с нестабильной молокоотдачей, изменяющейся даже при строжайшем соблюдении режима дойки, препятствует повышению производительности труда доярок.

\section{Выводы}

1. Продолжительность подготовительного массажа вымени должна соответствовать времени латентного (скрытого) периода рефлекса молокоотдачи.

2. Как различные термические воздействия на вымя, так и массаж оказывают одинаковое влияние на скорость молокоотдачи, количество и житнность молока.

3. Нарушение стереотипа доения (нерегулярное чередование машинной дойки с ручной) вызывает торможение молокоотдачи и увеличивает продолжительность доения.

4. Повышение частоты ритма пульсации в доильной машине вдвое против обычного вызывает сокращение времени дойки на $2,2-6,4 \%$.

5. Скорость молокоотдачи при машинном доении в большой мере зависит от тонуса сфинктера соска; при катетеризации сосков тугодойных коров скорость выдаивания значительно повышается. Однако у некоторых коров свойственные им колебания в скорости выдаивания сохраняются и после выключения сопротивления соскового сфинктера.

6. Скорость выдаивания при машинном доении в значительной мере определяется индивидуальными особенностями нервной системы животного.

\section{ЛИТЕРАТУРА}

1. Жолни ренко А. М., Новое в организации труда на ферме крупного poratoro скота. М., 1954.

2. Ко ро ле в В. Ф., Машинное доение коров. М., 1953.

Эстонский научно-исследовательский институт животноводства и ветеринарии

Поступила в редакцию $\begin{array}{lll}7 & \text { IX } 1957\end{array}$ 


\section{PIIMAEJEKTSIOONIREFLEKSI UURIMINE MASINALUPSI PUHUL}

\section{E. Valdmann}

\section{Resümee}

Käesoleva töö käigus uuriti udara massaaži ja temperatuurärritite, lüpsirežiimi muutmise ja lüpsimasina pulsaatori töö sageduse mōju piimaejektsioonirefleksile lehmadel, samuti lehmade individuaalsete erinevuste iseloomustamise võimalust piimaejektsioonirefleksi kaudu masinalüpsi tingimustes.

Piimaejektsiooniprotsessi objektiivne uurimine toimus graafilisel registreerimismeetodil automaatkaalude ja kümograafi abil. Katsed tehti kahetsüklilise laudarežiimi (Zolnirenko järgi) tingimustes, mille juures lehmade ööpäevane piimahulk protsentides jagunes vastavalt lüpsidele: I $-34,6 \%$, II $-17,7 \%$, III $-33,8 \%$ ja IV $-13,9 \%$.

Suurimat lüpsikiirust täheldati põhilüpside (I ja III) juures. Täiendavates lüpsides (II ja IV), vaatamata vähemale piimahulgale, pikenes lüpsmise kestus 1,05-1,75 korda, vōrreldes põhilüpsidega. Märgatavalt pikenes täiendavates lüpsides piimaejektsioonireโleksi latentsusperiood (72-238 sek. põhilüpside $20-95$ sek. vastu).

Uurides udara ettevalmistusmassaaži mõju lüpsi kiirusele osutus optimaalseks massaaž, mis oma kestuselt oli vőrdne piimaejektsioonirefleksi latentsusperioodiga. Udara masseerimise tagajärjel piimaejektsioonirefleksi latentsusperioodi vältel lühenes masinalüpsi kestus põhilüpside ajal $17,8-29,3 \%$ ja täiendavates lüpsides kuni $50 \%$, vōrreldes lüpsi kestusega ettevalmistamata udara korral.

Vōrdlevad katsed udara pesemise kohta erineva soojusega vees niisutatud rätikuga (vee temperatuur $+10,+32-36$ ja $+52-56^{\circ} \mathrm{C}$ ) ja udara massaaži kohta kuiva riide abil näitasid, et kuuma veega pesemisel ei ole mingeid eeliseid teiste udara ettevalmistamiseks kasutatud vôtete ees. Piimaejektsiooniprotsessi iseloom jäi kōigi nimetatud manipulatsioonide juures praktiliselt ühesuguseks. Samuti ei muutunud ööpäevane piimahulk ja piima rasvasisaldus.

Harjumuspärase lüpsirežiimi rikkumine, mis seisnes masinalüpsi ebaregulaarses vaheldumises käsitsilüpsiga, põhjustas masinalüpsi kestuse pikenemise 11,3-260\% vōrra.

Katsed lüpsimasina pulsaatori pulsatsioonisageduse mõjust piimaejektsioonirefleksile andsid järgnevaid tulemusi.

Vōttes lüpsimasina pulsaatori töötamise puhul 48 korda minutis lüpsi kestuseks $100 \%$, oli pulsatsioonisagedusel 24 korda minutis lüpsiaeg eelmisega vōrreldes $26,3-50 \%$ võrra pikem. Pulsaatori töötamisel 96 pulsatsiooni minutis lühenes lüpsiaeg 97,8-93,6 protsendile, seega $2,2-6,4 \%$ võrra. Pulsaatori töö sagedusel 150 pulsatsiooni minutis lühenes lüpsmise kestus $5,3-8,7 \%$, võrreldes lähteandmetega.

Katsetes kateetritega nisasfinkteri toonuse väljalülitamisel lühenes märgatavalt lüpsmise kestus kõvanisalistel lehmadel. Kateteriseeritult täheldati siiski mōningatele lehmade'e omaseid kōikumisi lüpsmise kiiruses.

Körvuti anatoomilise faktoriga (tugev nisasfinkter) avaldavad masinalüpsi kiirusele olulist mõju lehmade närvisüsteemi iseärasused.

\section{Eesti Loomakasvatuse ja Veterinaaria Teadusliku Uurimise Instituut}




\title{
A STUDY ON THE REFLEX OF MILK-EJECTION IN CASE OF MACHINE MILKING
}

\author{
E. Valdmann
}

\section{Summary}

In the present work the author has studied the influence of the massage of the udder, of washing the udder with water of different temperature, of the change of milking regime, and of different pulsator speeds on the reflex of milk ejection in cows.

The author has also investigated the possibility of characterizing the individual peculiarities of cows by the reflex of milk-ejection in the conditions of machine milking.

The objective investigation of the process of milk ejection was carried out by graphic registration by means of automatic scales and kymograph.

The experiments were performed in the conditions of two-cyclic shed regime (after Zholnirenko). The daily amount of milk by cows according to the milkings was as follows (in per cent): I - 34.6; II - 17.7; III - 33.8; IV - 13.9.

The highest milking rate was observed at the first and the third milkings. At the second and the fourth milkings, in spite of the lesser amount of milk, the duration of milking increased 1.05-1.75 times as compared with the first and the third milkings. The latent period of the reflex of milk ejection at the second and the fourth milkings increased considerably $(72-238 \mathrm{sec}$. as to $20-95 \mathrm{sec}$. by the 1 st and the 3rd milkings).

Studying the influence of the duration of the preparatory massage of the udder to milking rate, the optimum proved to be a massage, the duration of which was equal to the latent period of the reflex of milk-ejection. When massaging the udder during the latent period of the reflex of milk ejection, the duration of machine milking decreased 17.8-29.3 per cent at the 1st and the 3rd milkings and up to 50 per cent at the 2nd and the 4th milkings as compared with the duration of milking in case of the unprepared udder.

Comparative experiments with washing and massaging the udder with a towel wetted in water with a temperature of $+10,+32-36,+52-56^{\circ} \mathrm{C}$ and massaging the udder with a dry cloth showed that the washing with hot water has no advantage over the above-mentioned methods of preparing the udder for milking. The character of the process of milk ejection remained practically the same at all these manipulations. The daily amount of milk and its lat content did not change as a result of these influences.

The breaking of habitual milking regime in the form of the irregular alternation of machine milking with hand milking caused an increase in the duration of machine milking by $11.3-260$ per cent.

Experiments on the influence pulsator speeds to milk ejection gave the following results. Considering the duration of milking 100 per cent when the milking machine works at 48 pulsations a minute, the duration of milking comparing with the preceding one was $126.3-150$ per cent at the speed of the pulsator 24 times a minute, i. e. it was longer by $26.3-50$ per cent. When the pulsator worked at 96 pulsations a minute, the duration of milking decreased to $97.8-93.6$ per cent, i. e. it decreased by $2.2-6.4$ per cent, with the pulsator working at 150 pulsations a minute the duration of milking decreased 5.3-8.7 per cent as compared with the check data.

In experiments where the tone of the teat sphincters had been excluded with milk catheters, the duration of milking decreased considerably with hard milkers; fluctuation was observed, however, by some cows in milking rate.

Besides the explained anatomical factor (hard teat sphincter) the peculiarities of the nervous system of the cows strongly influence the milking rate by machine milking. 